\title{
Local government reform: compromise through cross-cutting cleavages ${ }^{1}$
}

\author{
Jan Erling Klausen, Jostein Askim, and Tom Christensen (University of Oslo)
}

Accepted 17-Oct-2019 for publication in Political Studies Review

\begin{abstract}
Public sector reforms often take place in heterogeneous reform environments. Key political, administrative, and societal actors often advocate different definitions of problems and solutions. A major leadership challenge is to choose a reform strategy that ensures the requisite level of support, even when the initial conflict structure is highly complex. Using cleavage theory, we develop assumptions about how the reform leader's assessment of the initial conflict affects the leader's choice between three distinct reform strategies. These assumptions are applied to a case study of a complex and contested public sector reform, Norway's national local government reform. We show how the government's choice of a reform strategy can be understood in light of cleavage theory, and discuss the implications of these findings for further theory development.
\end{abstract}

\section{Introduction}

Preparing, formulating, and implementing comprehensive administrative reforms could be seen basically from the actions of hierarchically dominant public leaders. In reality, however, such reform processes tend to be characterized by negotiations among several political, administrative, and societal actors (Pollitt and Bouckaert, 2017; March and Olsen, 1983) because of heterogeneity in structures, demography, interests, norms, and values in public organizations and their environments (Olsen, 1983). The broader the reform, the more complex the reform ecology, that is, the structure of participants, their interests, the problems, and the solutions they advocate and their resources. And the more complex the reform ecology, the more challenging leading and implementing the reform tend to be (Patashnik, 2008; Aberbach and Christensen, 2014).

We explore how political and administrative leaders link reform outcomes to the structure of the reform ecology. Building on Askim and Christensen (2009) we argue that cleavage theory can be used for understanding this interlinkage, especially when synthesized with decision-making theory. Cleavage theory builds on the assumption that the choice of

\footnotetext{
${ }^{1}$ The article is a publication from the project Reshaping the Map of Local and Regional Self-Government. A study of the Norwegian Local Government Reform (NLGR) processes 2014-2019. Research Council of Norway (project \# 255111).
} 
strategy for managing complex reform environments depends on the reformer's assessment of the initial conflict structure (Ross, 1920; Knutsen, 2005). We identify three optional reform strategies and develop assumptions about the appropriateness of each strategy given the pattern of conflicts between actors.

We demonstrate the value of cleavage theory for reform scholarship via a case study of the decision-making process leading to a decision to undertake a major and a contested public sector reform, specifically one whereby Norway decided to reduce the number of municipalities from 428 to 356.

The focus is on the formation of public sector reform, in this case the trajectory from 2013 to 2017, rather than on the reform's implementation or effects. This focus allows for a fruitful meeting strands of scholarship on reform, decision-making, and political leadership.

The main research questions are accordingly:

- Who were the main actors in the decision-making process leading up to the reform?

- What were the cleavages among these actors in terms of their interests, problem definitions and preferred solutions?

- Can the cleavage structure explain the extent to which it was possible to compromise on mergers and, more broadly, to reach the reform's goals?

To answer these questions, we track reform leaders' formulation of a problem diagnosis, construction of a solution to the problem, and mobilization of support for the chosen solution - three principal tasks for political leaders (Tucker, 1995). By closely following the reform's formation, we can observe elements of these three tasks as sequential steps and can also observe elements of reciprocity between them.

The article's first main section contains a description of the theoretical framework, which includes a synthesis cleavage theory and decision-making theory. The second section concerns data collection, mainly interviews with political and administrative elites. The third contains a description of the reform. The empirical focus is on the process at the national central government level, primarily the political parties and their actions in the cabinet and the Parliament; processes at regional and municipality levels are included only insofar as they affect the reform at the national level. Further, the focus is on the 'winning coalition' built by the governing parties and their supporting parties, meaning that we will not discuss why it was not possible to build a more encompassing consensus on the mergers, reaching across the 
main position/opposition fault. The final section contains an analysis of the reform as a case using the theoretical framework and contains answers to the research questions.

\section{Heterogeneity and decision-making}

Heterogeneity in formal structures, demography, interests, and in informal norms and values characterizes many public organizations (March and Olsen, 1983). The environments of public organizations are often heterogeneous as well. Heterogeneity constrains decisionmaking processes and reforms and limits the scope for means-ends thinking and hierarchical control (Dahl and Lindblom, 1953). Public organizations often make decisions through negotiations between a wide range of participants and outcomes are therefore often unpredictable (Olsen, 1983). Because goals and means are contested among participants in the decision-making process, competing definitions of problems and solutions tend to coexist. Leaders of public organizations to some extent relinquish authority by being unable to control access to decision-making processes. On the other hand, an inclusive approach to decision-making might increase the legitimacy of decisions, because non-restrictive access is associated with democratic and open decision-making (Mosher, 1967). There is, in other words, a trade-off between control and participation, with implications for legitimacy.

Decisions can be seen as frozen conflicts, in the sense that they perpetuate the power balance between competing actors at the time the decision was made. Historically, some actors and interests might have enjoyed more prominent representation in a policy or structure than others, because of wins in even earlier political battles. As Schattschneider (1960) emphasizes, organization is mobilization of bias. At the outset of new reforms, leaders often need to strike a balance between defending the position of the winners and improving the situation of the losers. Nevertheless, reform processes are often characterized by conflicts, because some actors have vested interests in the status quo, while others hope to further their interests and increase their influence.

One way of making decisions under heterogeneous conditions results from the emergence of winning coalitions between groups of actors (Thompson, 2017). Winning coalitions can be brutal, with winners' preferred goals dominating decisions. Alternatively, winning coalitions can be softer, meaning that the win accommodates some of the loser's goals. Winners choose soft wins when the underlying conflict is shallow enough to allow inclusion of some of the loser's goals without reducing the attainment of one's own main 
goals. Furthermore, a soft solution is chosen because the winner realizes it might be a minority next time a decision is made (Lipset et al., 1956).

A second way of making decisions under heterogeneous conditions is to compromise after sounding-out processes and negotiations that give more actors influence over the final decision (Olsen, 1972; March and Olsen, 1983). Compromises are likely when the actors hold complex views and try to reconcile them. Cross-cutting cleavages therefore facilitate reaching compromises.

The third way is quasi-solution of conflicts and sequential attention to goals (Cyert and March, 1992). So-called 'log-rolling' is an important characteristic: actors promise each other support on different issues at different points in time, thus solving short-term problems where pressure for consistency is low. As the term 'quasi-solution' implies, this does not solve a problem in a strict sense; it leads to inconsistency in the long term because it is about agreeing to disagree.

Political behaviour and election theory see cleavages as differences among actors in opinion along a dimension (Lipset and Rokkan, 1967; Knutsen, 2005). A cleavage might be based on, for example, class, ethnicity, political ideology, culture, geographical location, professional background, or institutional affiliation. If actors systematically hold opposing views on question after question, conflictual decision-making is likely (Ross, 1920; Coser, 1998). Cleavages will, however, often cut across each other. Actors disagree on some issues and agree on others, thereby reducing polarization and conflicts in decision-making related to reforms. Cross-cutting cleavages might cancel each other out (Ross, 1920; Coser, 1998).

Cleavage characteristics might restrict the choice of decision solution, in the sense that overlapping and cross-cutting cleavages do not accommodate each decision solution equally well. 'Winning coalitions', the first decision solution, is most feasible when cleavages overlap. A winning coalition is not motivated to seek reconciliation with the minority and can choose to disregard opposing views. A hard version of the winning coalition solution might come about in situations where the reformist government commands a majority in parliament, when there is strong polarization on dominating issues and weak cross-cutting cleavages. A softer version of the winning coalition solution is marked by compromise on peripheral or non-essential issues - including elements of the minority's position in the final decision. To the extent that the minority has well-reasoned arguments, this strategy might serve to improve the quality of complex decisions. Giving small concessions to the minority might furthermore make future life in opposition more pleasant. A soft version of the winning coalition solution is probably most likely in cases where the 
reform is carried out by a minority coalition government and in situations where a crosscutting pattern of cleavages precludes stable coalitions.

The second decision solution, 'compromise', is appropriate when cleavages are crosscutting (March and Olsen, 1983). Because cross-cutting cleavages frustrate formation of stable coalitions, the only way to keep the reform going is by making trade-offs with varying constellations of actors. Absent a centre of authority, however, pluralism might end up in conflicts and chaos. Compromise might require firm reform leadership, and a degree of pragmatism among leading actors.

'Quasi-resolution of conflict and sequential attention to goals' (Cyert and March, 1992), the third decision solution, is not a compromise at one given moment, but a compromise that extends over some period of time. Actors on opposite sides of a cleavage might agree to have their interests fulfilled at different points in time, either because of their pragmatic adaptation or because intensity of preferences varies (i.e., one has strong preferences on one issue but is indifferent on another). Such agreement might produce fewer conflicts and more legitimacy in the short term, but also might produce low policy consistency. Another version of this third decision solution is that some main issues, related to deep and overlapping cleavages, are decided at one point in time, while cross-cutting cleavages are dealt with later on, an approach which caters to different actors, because there is a time sequence in the reform decision-making process. Main preconditions for this decision solution might be that a political-administrative system have competing authority centres, or that cleavages be too deep to reach a 'real compromise'. These preconditions might exist in checks-and-balance systems and in systems where minority cabinets are the norm. We will try to find elements of quasi-resolution of conflict and sequential attention to goals in the municipal merger reform.

\section{Data}

Between May and August 2017, we interviewed 13 individuals who were important actors in one or more phases of the Norwegian municipal amalgamation reform. Six interviewees were parliamentarians: members - from across the party spectrum - of the Norwegian Parliament's Standing Committee on Local Government and Public Administration. Three were politicians in the Ministry of Local Government and Modernisation: the minister and two state secretaries. Three were senior civil servants in the Ministry of Local Government and Modernisation. In addition, the leader of the board of the Norwegian Association of Local 
and Regional Authorities (KS) was interviewed. We have furthermore studied public documents that describe the background, motives, and organizational solutions proposed in different phases of the process, for example assessment reports, government documents, reports, and proposals to Parliament and minutes from parliamentary debates.

\section{The Norwegian municipal amalgamation reform}

At the outset of the reform, Norway had 428 local governments and 19 county governments. Norway's local government system was established in 1837 with 392 units. It since gradually fragmented to 744 units in 1950 and, next, consolidated to 451 after a reform in the 1960s. This structure has since remained largely intact except for a few voluntary mergers and some amalgamations due to restructuring of urban areas in the 1990s (Hansen, 2016).

In 2014, the Norwegian government initiated a reform of the local government system. The reform aimed at reducing the number of local governments, in order to boost the quality of service delivery, expand the territorial scope for planning, ensure correct exertion of legal authority, and allow reduced central government supervision (KMD, 2014a).

Parliament made the final decision on the future local government structure in June 2017. Principal reform events are presented in Table 1.

Table 1: Reform timeline

\begin{tabular}{ll}
\hline 2013 (Oct.) & Reform presented in the Solberg government's accession agreement \\
2014 (May) & Proposal on local government reform presented to Parliament \\
2014 (May) & Proposal of bill regulating loans, etc. at a public hearing (shelved in Sept.) \\
2014 (June) & Parliament decides on a local and county government reform \\
2014 (Aug.) & Local governments invited to commence assessments and negotiations \\
2015 (Dec.) & Proposal for revised local government grants system at a public hearing (decided in \\
& April) \\
2016 (April) & Report to Parliament on county government reform \\
2016 (May) & Annual proposition on local government finances \\
2016 (July) & Initial deadline for submission of local amalgamation proposals is extended. \\
2017 (Feb.) & Presentation of negotiated agreement on local and county government reform \\
2017 (April) & Presentation of full reform proposal to Parliament (decided in June) \\
2017 (Dec.) & Proposals on reversing enforced amalgamations voted down in Parliament \\
\hline
\end{tabular}

Following parliamentary elections in 2013, the Conservatives and the Progressives formed a minority government lead by Prime Minister Solberg. The government relied on a support agreement signed by the Christian Democrats and the Liberals. Either of these two parties commanded enough seats to provide a parliamentary majority together with the seats 
commanded by the two government parties. The government's accession agreement conveyed the four parties' shared intent to reform the local government system. It was 'the first item the four parties agreed on', according to one informant.

The government submitted a reform proposal to Parliament in May 2014. The government tried to set in motion voluntary local amalgamation initiatives by using information, arguments, financial incentives, and procedural prescriptions.

Because voluntary amalgamations are seen as uncontroversial or even desirable by most, if not all, political parties, the chosen reform strategy would seem to enable a national 'forlik' - a compromise with broad or complete cross-partisan support: the default approach to major public sector reform in Norway's parliamentary history (Grønlie, 2017).

At first, this attempt at compromise appeared successful, because Labour declined to support a motion put forth by two other opposition parties to delay the reform. However, rising controversy over one particular issue soon threatened to break the consensus. The government had proposed that enforced amalgamations, decided by Parliament despite local dissent, could take place in 'a few [cases] where individual local governments must be prevented from blocking changes that are necessary in light of regional considerations' (KMD, 2014c: 51). The Government deliberately borrowed this wording from Labour's manifesto - a wording similar, in fact, to that used by a Labour government that forced rural local governments to merge with their urban neighbours in the 1990s (Hansen, 2016). Still, after increasing within-party resistance, Labour withdrew its support for the Government's line on this issue in April 2015. ${ }^{2}$

While some informants allege that the Government at first attempted to negotiate a cross-partisan agreement on the reform, others portray such attempts as perfunctory. The minister of Local Government and Modernisation said he and the prime minister held a consultative meeting with all party leaders in Parliament 'early in 2014', during which the leader of Labour said he 'did not want to make an advance agreement about the reform. (...) The government would have to present their reform proposals and then the discussion would take place in [the Parliament]'. Labour's senior representative on the parliamentary Standing Committee on Local Government and Public Administration said, however, that her party 'expected to be invited to negotiations that could lead to a broad agreement; a 'forlik' was in the air. (...) But it never happened. (...) They came [to negotiate a compromise] one or two

\footnotetext{
2 'We will respect the local answers. Amalgamation of municipalities should be on a voluntary basis' (Labour Party meeting 2015). Decided opinions related to the local elections, etc. Opinion no 4. pp. 11. https://res.cloudinary. com/ arbeiderpartiet/image/upload/v1/ievv_filestore/19638b0c79ce47 aea62b2f977d6 a8 1775aeea41 bd9d841f88c 96905 44fa 19 $\mathrm{c} 3 \mathrm{f}$
} 
days before they submitted the proposal [in May]'. One informant noted growing exasperation with the government for 'overselling' Labour's initial support for enforced amalgamations.

Regardless of the prospects for enforced amalgamations, the government kicked off the reform on a voluntarist note. In August 2014, all local governments were instructed to assess relevant options for amalgamation, and to submit - pending successful negotiations with their neighbours - amalgamation proposals by January 2016, or by July 2016 at the latest (Klausen, Askim and Vabo 2016). The County Governors - state territorial representatives - were tasked with co-ordinating the negotiation processes regionally, with the aim of submitting reports on the outcome of the voluntary processes by the fall of 2016 , something they did with varying degrees of enthusiasm.

From early on, a commonly held position was that structural reform of the local governments necessitated reform of the county governments as well. The Government initially proposed to postpone structural reform of the county governments until after the local government reform had been implemented (KMD, 2014b: 49). This delay was a way of tackling categorical disagreement between the government parties and the supporting parties. Whereas the two parties in government wanted to terminate the middle level of government altogether, the supporting parties wanted a stronger middle level of government. The Government proposed that the county government system would remain 'until there is a robust local government structure with new tasks and services' (KMD, 2014b: 49) and to transfer tasks from county governments to local governments.

The supporting parties did not accept these proposals. In February 2014, the Liberals proposed to establish 'a new, elected regional level of government to replace the extant county governments'. ${ }^{3}$ The ensuing parliamentary debate evinced a majority for retaining a reformed regional level of government and, importantly, that this reform should occur not after but in tandem with the local government reform. ${ }^{4}$ According to several informants, the Liberals and the Christian Democrats forced the government parties to support this position. Consequently, in April 2016, the Government submitted a report to Parliament on a regional reform. ${ }^{5}$ Similar to the local government reform, county governments were to initiate regional assessments and negotiations in order to reach agreement on amalgamations.

\footnotetext{
${ }^{3}$ Dokument 8:26 S (2013-2014). A proposal from the Parliamentary representatives André N. Skjelstad, Ketil Kjenseth og Trine Skei Grande on the development of a new elected regional level instead of the county government (26/2-2014)

${ }^{4}$ Innst. 262 S (2013-2014), Innst. 300 S (2013-2014)

${ }^{5}$ Meld. St. 22 (2015-2016). New elected regions - role, structure and tasks.
} 
Negotiating the final agreement on local government reform in February 2017, the supporting parties traded support for the local government reform for support for structural reform of the regional governments.

As a negotiation tactic, the Liberals and the Christian Democrats - who wanted the regional reform - wanted to ensure that [the regional reform] was actually decided, and so they needed to couple the two reforms temporally (interview 12, p. 14).

The Liberals as well as the Christian Democrats feared that if we could not couple the regional reform to the local government reform, there would never be a regional reform. We believed that this was the last chance for saving the elected regional level (interview 3, p. 8).

From the outset of the reform, the Government feared that 'the present municipal council can invest and roll the costs onto the new, larger municipality' (Prop. $95 \mathrm{~S}$ (2013-2014): 50). The government therefore prepared a bill on regulating loans and long-term rental agreements for the period 2015-2017. Put out for public consultation in May 2014, the proposal pointed at the need to 'prevent purely strategic adaptations in anticipation of the local government reform', and to prevent that local decisions on 'loans, investments, and localization [of new buildings] create disagreement among municipalities that are candidates for amalgamating' (KMD, 2015b: 3). A total of 140 municipalities registered disagreement with the proposal, as did all the parties in Parliament, including the two supporting parties. According to the informants, the government shelved the proposal because of a lack of support from its supporting parties: 'We could not get the Christian Democrats and the Liberals to go along with the loans thing. So we just dropped it'. (interview 12, p. 2).

Norway's local government sector is funded by local taxation, user fees, and a composite scheme of central government funding instruments. This scheme includes a grant that compensates small local governments for above-average administrative costs. In December 2015, the government proposed to reduce this compensation (KMD, 2015a) in an attempt to promote amalgamations by punishing local governments that, by refusing to amalgamate, had failed to reap economies of scale. More than 300 local governments registered strong dissent in a public consultation. Many saw the proposed cutbacks as de facto enforced amalgamation. Most trade unions also dissented; they claimed that reduced grants would harm service provision. The Norwegian Agrarian Association and the Association of Hydropower-producing Local Governments voiced similar concerns. The 
proposal was, however, supported warmly by Norway's largest employers' association, NHO.

The parliamentary opposition, the Socialist Left, Labour, and Centre parties, also rejected using the funding scheme as a reform tool. The Christian Democrats abstained from negotiations over the grants system, in line with their overall strategy as a supporting party. By declining to take part in negotiations prior to the formal submission of proposals to Parliament, the Christian Democrats would be in a less constrained position in the committee. They saw the proposed adjustments as a departure from voluntarism and as an inappropriate change of the 'rules of the game' halfway into the reform. The Christian Democrats' refusal to partake in negotiations over the adjustments to the grants system effectively decoupled the party from the remainder of the reform process. However, the government had already secured a parliamentary majority for revising the grants system by means of a negotiated agreement with the Liberals. ${ }^{6}$ Thus, in May 2016, the government decided on a scheme that slashed grants to 'voluntarily small' local governments by about half as much as initially intended (KMD, 2016). ${ }^{7}$

The Liberals had agreed to support the revised grants system in return for concessions from the government parties on a separate issue: moving central government functions and jobs from the capital Oslo to the periphery. Agencies provide prestige and attractive job opportunities for highly skilled workers. ${ }^{8}$ The Liberals has been a long-standing supporter of this policy (Sætren, 2016), and the local government reform provided them with political leverage.

In January 2016, at the time of the first deadline, only 11 local governments had applied for amalgamation. Although the reform did pick up speed by the final July 2016 deadline for amalgamation proposals, it soon became clear that large swaths of the local government structure would remain intact. Consequently, the issue of enforced amalgamations resurfaced. Following negotiations behind closed doors between MPs from the two government parties and the two supporting parties, a political agreement on the reform of local and county governments was reached and announced in February 2017. The agreement secured a majority in Parliament for enforced amalgamation of 36 local governments into 11 new units - in addition to 85 local governments that had decided

\footnotetext{
${ }^{6}$ Agreement of 21.4.2016 on a new funding scheme for local governments between the Conservatives, the Progressives and the Liberals (unpubl.).

7 This proposition describes economic developments in the local government sector, and present key features of related government policies. Grants are however decided at the end of the year, as part of the annual state budget process.

${ }^{8} \mathrm{https}$ ://www.venstre.no/artikkel/2017/08/01/besokte-politiets-lonns-og-regnskapssenter/
} 
voluntarily to amalgamate into 36 new units. The number of county governments would be reduced from 19 to 10 .

According to informants, agreement on each case of enforced amalgamation came as the result of assiduous political bartering between the four parties' representatives in the parliamentary committee. These four MPs travelled the country extensively to gauge local opinion, thus assuming an unusually active role in terms of laying down the groundwork for the government's proposal to Parliament. Because enforced amalgamations were highly controversial, all four parties tried to avoid alienating voters in local strongholds.

It was, in a way, a give and take between different parties. Some parties had important geographical considerations (interview 12, p. 10).

The Progressives and the Liberals were very concerned about individual local governments. They probably had strong relations with prominent local party figures. (interview 3, p. 12).

While the Christian Democrats were part of the political agreement signed in February 2017, they declined to support the eight cases involving enforced amalgamation, fearing electoral retributions As a result, the Liberals' bargaining position was strengthened; the Government could no longer get the reform through Parliament without the support of the Liberals. In addition to strong-arming the government into agreeing on a county government reform, the Liberals kept pushing for decentralization of governmental agencies. As a result, jobs in the Police Directorate and in the Tax Authority were moved from Oslo to Kristiansund. ${ }^{9}$

The government's proposal to Parliament passed on 8 June 2017 with the slimmest possible majority. Their voting against the enforced amalgamations did not mean that the Christian Democrats had jumped ship altogether. In 2017, the opposition parties stated that they would reverse enforced amalgamations if they won a majority in the general election later in the same year, thus releasing a clause in an informal agreement between the Government and the Christian Democrats. As one Government representative said: 'We had an agreement. The Christian Democrats are free to vote against [enforced amalgamation proposals on 8 June], but they will not support proposals on reversal. In return, the government supports the county government reform' (interview 13, p. 13). The Christian Democrats remained largely true to this commitment, declining to support all but one reversal proposals by the opposition in December 2017.

\footnotetext{
${ }^{9}$ Vil flytte ut mer fra de store byene (Would move out more from the big cities). Tidens krav, Trond Hasselø, 31 July 2017.
} 
We have seen that the reform from early on activated a broad spectrum of actors, opinions, and interests. While the government made somewhat feeble attempts to reach a broad consensus at the outset, actors outside of the governing coalition were soon effectively

Table 2: Cleavages and party positions

\begin{tabular}{lll}
\hline Cleavage & Position I & Position II \\
\hline $\begin{array}{l}\text { Enforced } \\
\text { amalgamation }\end{array}$ & $\begin{array}{l}\text { Some enforced cases: Conservatives, } \\
\text { Progressives, Liberals, Labour (before } \\
\text { 2015), Christian Democrats (before 2017) }\end{array}$ & $\begin{array}{l}\text { No force, voluntarily only: Labour } \\
\text { (from 2015), Christian Democrats } \\
\text { (from 2017) }\end{array}$ \\
$\begin{array}{l}\text { Financial reform } \\
\begin{array}{l}\text { incentives } \\
\text { Legal regulation of fiscal } \\
\text { behaviour: Conservatives, Progressives }\end{array}\end{array}$ & $\begin{array}{l}\text { No new law: Liberals, Christian } \\
\text { Democrats }\end{array}$ \\
$\begin{array}{l}\text { Substantially reduce grants for } \\
\text { voluntarily undersized local governments: } \\
\text { Conservatives, Progressives } \\
\text { government }\end{array}$ & $\begin{array}{l}\text { (...) to a lesser extent: Liberals, } \\
\text { Christian Democrats }\end{array}$ \\
$\begin{array}{l}\text { Terminate: Conservatives, Progressives } \\
\text { geventralize }\end{array}$ & $\begin{array}{l}\text { Strengthen: Liberals, Christian } \\
\text { Democrats }\end{array}$ \\
& Strongly pro: Liberals & $\begin{array}{l}\text { No known initial position: } \\
\text { Conservatives, Progressives, } \\
\text { Christian Democrats }\end{array}$ \\
\hline
\end{tabular}

shut out and denied further influence. Consequently, key elements of the reform were decided as negotiated settlements between the government parties and the supporting parties. Major cleavages are summed up in Table 2.

Negotiations over these cleavages resulted in a watered-down reform, with weaker financial incentives and reduced credibility for the threat of enforced amalgamation. Negotiations also resulted in an unplanned county government reform and in an unplanned moving of public jobs to the periphery.

\section{Discussion}

We initially described three strategies for managing heterogeneous reform environments. First, reform leaders can establish a winning coalition if there exists a large enough coalition of actors (such as political parties) whose cleavages overlap (March and Olsen, 1983). Second, if cleavages are cross-cutting, reform leaders can compromise through sounding out and negotiations (Olsen, 1972). The third strategy is to defer from resolving conflicts and instead keep the reform going by addressing short-term problems pragmatically as they come, 
attending to problems sequentially, and if need be, bypassing emerging problems by means of quasi-solutions (Cyert and March, 1992). Because the third strategy potentially jeopardizes a reform's consistency the most, it should be considered a last-resort option, one chosen when the other strategies do not work, because of particularly deep-set or complex cleavages.

The case under study shows that all three strategies can be used in the formation of a complex and contested public sector reform. In the early stages of Norway's amalgamation reform, the government, in line with the country's parliamentary history, attempted to establish a broad cross-partisan winning coalition, one that included the largest opposition party, which had signalled support for the government's reform, but excluding other opposition parties that were clearly against the reform (Christensen, 2003). The government assumed that cleavages between itself, its supporting parties, and Labour were sufficiently overlapping to see the reform through to legislation. The Government was soon forced to abandon the broad coalition strategy, though; it was premised on overly sanguine assumptions about Labour's willingness to support the reform. Labour's support evaporated following pressure from the party's grass roots and after the party's leadership realized that, politically, there were probably no rewards to be reaped by shouldering responsibility for a generally unpopular reform.

Consequently, the government changed strategy and narrowed down the range of partners to an only slightly oversized winning coalition comprising just the government parties and its two supporting parties in Parliament. It soon emerged, however, that the continued support of the Christian Democrats and the Liberals would come at a price. As the sole remaining guarantors of a parliamentary majority for an increasingly controversial reform, the Christian Democrats and the Liberals found themselves in a beneficial negotiating position vis-a-vis the government. The government tried to compromise to salvage the reform coalition. By agreeing to relax the reform's financial incentive structure, to have a concurrent county government reform, and to remove state jobs from the capital, it seemed the government was able to hold the coalition together, while largely denying other actors in the reform's environment any influence - despite often-rambunctious opposition.

In the final stage of the reform, however, the cleavage on enforced amalgamation proved too deep-set and the compromise broke down; again, the reform coalition was abridged, with the Christian Democrats jumping ship. The ultimate winning reform coalition was 'brutal', eventually relying on the narrowest possible margin of votes in Parliament.

Although the reform was marked primarily by narrowing winning coalitions through compromises between the parties involved, one can also say there were aspects of 'quasi- 
solution of conflicts and sequential attention to problems', in several ways. The government settled for a much more limited number of amalgamations, deferring the issue to a future time when conditions for further amalgamation might improve. So as March and Olsen (1983) point out, short-term problems and challenges might turn into potential long-term success, depending partly on how reforms mature and partly on the symbolic games surrounding them (Patashnik, 2008).

The government might have surmised that gaining acceptance for slashing grants to 'voluntarily small' municipalities could create a 'window of opportunity' for increasing the disincentives against amalgamation at a later stage (see Kingdon, 1984). Correspondingly, a limited number of enforced amalgamations in the early stages could potentially increase acceptance for top-down reform later on. Presumably, the government aimed high to create momentum, regardless of short-term rather limited changes.

Arguably, the government follow a 'bounded rational' strategy (Simon, 1957) - 'save what can be saved and pick your fights'. What could be saved was to secure the voluntary amalgamations. This seems to be the adjusted political goal and one that could be presented as a political victory - a first step in a further process of amalgamation. This is what Brunsson (1989) labels political 'double-talk', that is, talking as if the process was a big success even though it in reality produced limited results, considering the original goals.

The government did not pick many fights in reality, because giving in to the demands from the supporting parties was not that difficult. Early on, it became evident that political support for legal regulation of the fiscal behaviour of potential amalgamating municipalities was insufficient, as was the support for dissolving the counties. And, the revised view of the Christian Democrats on enforced amalgamation, on an expanded portfolio for counties, and on decentralizing governmental agencies implied minor changes. So, a modified stand from the government on incentives for 'voluntarily small' municipalities was one of the few aspects that ended in a compromise more to the government's initial liking.

The strategy of the two supporting parties, the Liberals and the Christian Democrats, can be characterized with Schattschneider (1960), as one of 'socializing' the conflicts and tensions by making the process more complex, in the hope of political gains. Another way to say this is that they 'created noise' in the process (Cohen and March, 1974), a strategy often used when actors are sceptical about letting other actors' problems and solutions dominate. One aspect of the so-called 'garbage-can theory' concerns coupling and decoupling of actors, problems, and solutions, and the choice of opportunities (March and Olsen, 1976). The amalgamation process is an example of the Liberals and the Christian Democrats trying to 
couple the future of the county governments and decentralizing of governmental agencies to the process, to improve their negotiation position, something that was challenging for the government. This strategy could also be seen as partly 'arena-shifting' (Flinders and Buller, 2006: 72-74), or more precisely shifting the focus to other related issues, to gain politically.

\section{Conclusions}

We asked initially if the cleavage structure among main actors could explain the extent to which it was possible to compromise on mergers and, more broadly, to reach the reform's goals. The analysis does support assumptions of congruence between cleavage structure and reform strategy. While overlapping cleavages indicate that building winning coalitions is a viable strategy, cross-cutting cleavages indicate a need for compromising or for using quasisolutions. The government chose to pursue the goals of the reform mainly by building winning coalitions, and by seeking compromise among coalition partners. But these coalitions winnowed down gradually as the reform progressed, as compromises became gradually more difficult to achieve. While the chosen strategies were successful in the sense that the final reform proposal was approved by the requisite majority, one is hard pressed to claim that the government was anywhere close to reaching the reform's goals, however. Comprising 356 units following the reform, the local government system remains fragmented and a long way from fulfilling the aims of 'robustness' and 'financial resilience' cited as the government's reform goals.

The value of cleavage theory is that it demonstrates how particular cleavage structures restrict the choice of reform strategy. The empirical analysis provides clues as to how cleavage theory might be elaborated. Firstly, while cleavage theory emphasizes the pattern of cleavages, the 'depth' of cleavages could be equally important. Cleavages might be deep-set or shallow (Braybrooke and Lindblom, 1970: 30), leaving varying room for compromise. A pattern of 'shallow' cross-cutting cleavages could even strengthen a winning coalition defined by deep-set overlapping cleavages, because disagreement on non-essential issues presents opportunities for arguing and bargaining - offering coalition partners 'small wins' (Weick, 1984; Weick and Quinn, 1999) as incentives for remaining in the coalition. The analysis seems to support this notion, particularly as regards the willingness of the Conservatives and the Progressives to compromise on issues that were unessential for reform implementation.

Secondly, the depth of cleavages might not always be apparent. Due to imperfect information about other actors (Eggertsson, 1990), the choice of strategy is normally to some 
extent premised on assumptions about the cleavages. Faulty assumptions might lead to a faulty choice of strategy, in turn jeopardizing reform implementation. The government defaulted by first overestimating the willingness of Labour to support the reform, and second by failing to gauge correctly the willingness of the Christian Democrats to go along with enforced amalgamations. Clearly, correctly assessing the true depth of cleavages is a major challenge for would-be reformers.

Thirdly, the temporal aspects of reform (Pierson, 2004; Pollitt, 2008) need to be taken into account. Cleavages might not remain constant - public opinion and the "national sentiment' (Kingdon, 1984) are susceptible to change, in turn affecting not least the preference intensities of political actors in the reform's environment. Long-drawn and highly profiled reforms that engage many actors in a reform's environments might be associated with increasingly volatile cleavage patterns, adding a layer of uncertainty for reform strategists.

Fourthly, large-scale public reforms are always to some extent 'open systems' (Scott, 2003) that interact with their environments, adding further elements of unpredictability. Attempts at containing the reform to a manageable subset of actors in the reform ecology might prove challenging. In the present case it proved impossible, because the reform, at least in principle, affected all of Norway's then 428 municipalities.

\section{References}

Aberbach JD and Christensen T (2014) Why reforms so often disappoint. The American Review of Public Administration 44: 3-16.

Askim J and Christensen T (2009) Cross-cutting cleavages and the dynamics of public sector reform. In: Roness $\mathrm{P}$ and Sætren $\mathrm{H}$ (eds) Change and continuty in public sector organizations. Bergen: Fagbokforlaget, 149-168.

Braybrooke D and Lindblom CE (1970) A strategy of decision: Policy evaluation as a social process. New York: Free Press.

Brunsson N (1989) The organization of hypocrisy: Talk, decisions and actions in organizations. Chichester: Wiley.

Christensen T (2003) Narratives of Norwegian governance: Elaborating the strong state tradition. Public Administration 81: 163-190. 
Cohen MD and March JG (1974) Leadership and ambiguity: The American college president. New York: McGraw-Hill.

Coser LA (1998) The functions of social conflict. London: Routledge.

Cyert RM and March JG (1992) A behavioral theory of the firm. Malden, MA: Blackwell.

Dahl RA and Lindblom CE (1953) Politics, economics and welfare. New York: Harper and Brothers.

Eggertsson P (1990) Economic behavior and institutions. Cambridge: Cambridge University Press.

Flinders M and Buller J (2006) Depoliticization, Democracy and Arena Shifting. In: Christensen T and Lægreid P (eds) Autonomy and Regulation: Coping with Agencies in the Modern State. Cheltenham UK: Edward Elgar.

Grønlie T (2017) Til forsvar for folkestyret: Stortinget etter 1945. Bergen: Fagbokforl.

Hansen T (2016) Kommuneinndelingen - fra lokale økonomiske klubber til statlige velferdsprodusenter. In: Klausen JE, Askim J and Vabo SI (eds) Kommunereform $i$ perspektiv. Oslo: Fagbokforlaget, 47-69.

Kingdon JW (1984) Agendas, alternatives and public policies. Boston: Little, Brown and Company.

Klausen JE, Askim J and Vabo SI (2016) Kommunereformen i Norge. In: Klausen JE, Askim J and Vabo SI (eds) Kommunereform i perspektiv. Oslo: Fagbokforlaget, 26-46.

KMD (2014a) Kommunereform. Meldingsdel i kommuneproposisjonen 2015 (Prop. 95 S). Oslo: Kommunal- og moderniseringsdepartementet.

KMD (2014b) Meldingsdel i kommuneproposisjonen 2015 (Prop. 95 S). Kommunereform. In: (KMD) K-om (ed). Oslo: Kommunal- og moderniseringsdepartementet.

KMD (2014c) Prop. 95 S. Kommuneproposisjonen 2015. Oslo: Ministry of Local Government and Modernisation.

KMD (2015a) Høring - forslag til nytt inntektssystem for kommunene. Høringsbrev av 16.12.2015. In: moderniseringsdepartementet K-o (ed). Oslo: KMD.

KMD (2015b) Høringsnotat - Forslag til nytt inntektssystem for kommunene. In: moderniseringsdepartementet K-o (ed). Oslo: KMD.

KMD (2016) Prop. 123 S. Kommuneproposisjonen 2017. Oslo: Ministry of Local Government and Modernisation.

Knutsen O (2005) The 'Criss-Cross' Thesis. On crossing of conflict lines and organizational membership. In: Larsen SU (ed) Theory and Methods in Political Science. The first steps to synthesize a discipline. Boulder, CO: Social Science Monographs (distributed by Columbia University Press).

Lipset SM and Rokkan S (1967) Party systems and voter alignments: Cross-national perspectives, New York: Free Press.

Lipset SM, Trow MA and Coleman JS (1956) Union democracy: The internal politics of the International Typographical Union, New York: Free Press.

March JG and Olsen JP (1976) Ambiguity and Choice in Organizations. Bergen: Universitetsforlaget.

March JG and Olsen JP (1983) Organizing Political Life: What Administrative Reorganization Tells Us about Government. The American Political Science Review 77: 281-296.

Mosher FC (1967) Governmental reorganizations: Cases and commentary: Ajoint project of the Inter-University Case Program, Inc. and the Institute of Governmental Studies, University of California. Indianapolis, IN: Bobbs-Merrill Company.

Olsen JP (1972) Voting, "Sounding Out", and the Governance of Modern Organizations. Acta Sociologica 15: 267-283. 
Olsen JP (1983) Organized democracy: Political institutions in a welfare state: The case of Norway. Oslo: Universitetsforlaget.

Patashnik EM (2008) Reforms at risk: What happens after major policy changes are enacted. Princeton, NJ: Princeton University Press.

Pierson P (2004) Politics in time: History, institutions, and social analysis. Princeton, NJ: Princeton University Press.

Pollitt C (2008) Time, policy, management: Governing with the past. Oxford: Oxford University Press.

Pollitt C and Bouckaert G (2017) Public management reform: A comparative analysis--into the age of austerity. Oxford: Oxford University Press.

Ross EA (1920) The principles of sociology: New York: The Century Co.

Schattschneider EE (1960) The semi-sovereign people: A realist's view of democracy in America. New York: Rinehart and Winston.

Scott WR (2003) Organizations: Rational, natural, and open systems. Upper Saddle River, NJ: Prentice Hall Pearson Education International.

Simon HA (1957) Models of man: Social and rational: Mathematical essays on rational human behavior in a social setting. New York: Wiley.

Sætren H (2016) From controversial policy idea to successful program implementation: The role of the policy entrepreneur, manipulation strategy, program design, institutions and open policy windows in relocating Norwegian central agencies. Integrating Knowledge and Practice to Advance Human Dignity 49: 71-88.

Thompson JD (2017) Organizations in action: Social science bases of administrative theory. London, England, New York, New York: Routledge.

Tucker RC (1995) Politics as leadership. Columbia: University of Missouri Press.

Weick KE (1984) Small wins: Redefining the scale of social problems. American Psychologist 39: 40-49.

Weick KE and Quinn RE (1999) Organizational Change and Development. Annual Review of Psychology: 361. 